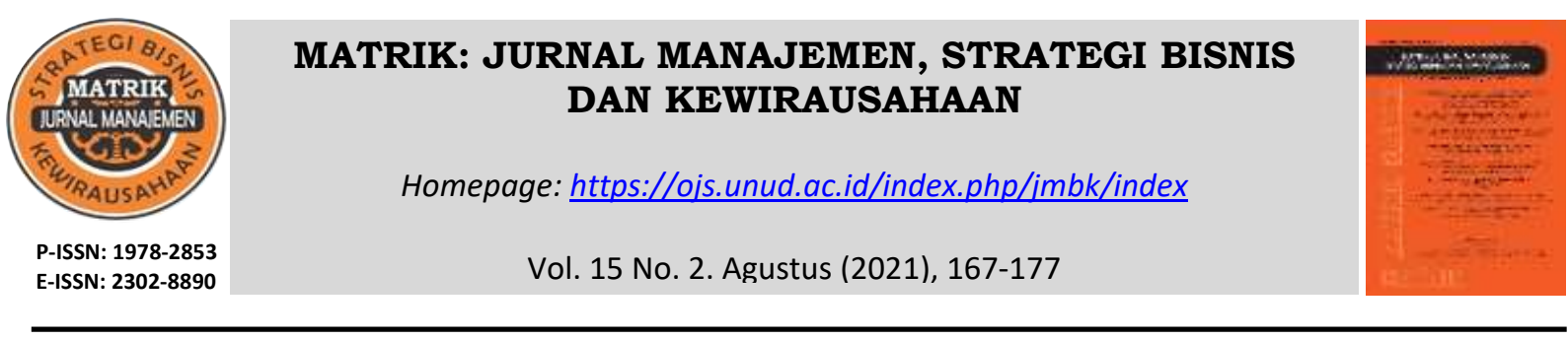

\title{
Non-Financial Variables Determining Performance Village Credit Institutions
}

\author{
Ni Luh Putu Wiagustini ${ }^{1)}$, I Made Andika Pradnyana Wistawan²), \\ ${ }^{1,2}$ Faculty of Economics and Business Udayana University \\ email: wiagustini@unud.ac.id
}

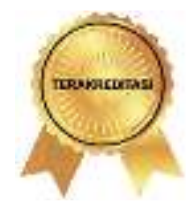

SINTA 2

DOI : https://doi.org/10.24843/MATRIK:JMBK.2021.v15.i02.p01

\begin{abstract}
The Village Credit Institution (LPD) as a rural microfinance institution, its operational activities are limited within the village area, experienced a fairly rapid development from eight units in 1984, reaching 1443 units in 2019, but there were 177 units (12.35 percent) not operating. The measurement of the performance of LPD is determined from the indicators of the level of health which are more assessed from financial ratios. In this study, non-financial variables were examined as variables that affect financial performance. This study aims to analyze the non-financial variables that determine the performance of LPD, which in this study are market orientation, entrepreneurial orientation, financial literacy, financial inclusion. The research population is LPD operating in Bali Province in 2019 as many as 1256 units. determined using the Slovin formula with an allowance of 10 percent, which is 93 units, Sampling with stratified proportional random sampling based on the health level of LPD, The method of analysis is Partial Least Square (PLS), it was found that the increase in entrepreneurial orientation, market orientation, financial literacy and the financial inclusion of the Village Credit Institution management has an impact on improving its performance. The implications for the management of the Village Credit Institution in improving its performance can increase entrepreneurial orientation, market orientation. financial literacy, management inclusion
\end{abstract}

Kata kunci: Entrepreneurship Orientation, Market Orientation, Financial Literacy, Financial Inclusion, and Performance

\section{INTRODUCTION}

The Indonesia Legislation Number 1 of 2013 concerning Microfinance Institutions was issued to stimulate the society economic activities to become superior, competitive, and independent, in order to improve the regional economy. One of the local wisdom-based microfinance institutions established in Bali is called a village credit institution (LPD), which is managed by Pakraman Village or the local community. The operating activities are limited inside the village area and it serves the people of Pakraman Village. This uniqueness is also a challenge for LPDs.

The number of LPDs in Bali have grown rapidly, from eight in 1984 to 1443 in 2019. Among them, 956 units (66.71 percent) fall in healthy category, 189 units ( 13.19 percent) in fairly healthy category, 93 units (6.49 percent) in less healthy category, 18 units (1.26 percent) 
in unhealthy category and 177 units (12.35 percent) are not operating (LPLPD, 2019). This study attempts to find solutions for the non-operating LPDs.

Determination of the healthy level of LPDs is based on the Bali Regional Regulation Number 3 of 2017, which mostly includes financial ratios, showing the financial performance. Accordingly, research on LPDs' financial performance measured by profitability ratios has been widely carried out. The results show that the level of cash turnover, lending and debt management effectiveness have positive effects on LPD profitability (Sutika \& Sujana, 2013); capital adequacy and liquidity ratios have positive effect on profitability, while non-performing loans have a negative effect on profitability (Krisnia Putri \& Mustanda, 2019); furthermore, deposit growth positively affects profitability (Kumalasari et al., 2014).

One of the weaknesses of the financial ratio is that it focuses on the short term performance, therefore an analysis of non-financial ratios as variables affecting LPD's performance is necessary, including variables of entrepreneurial orientation, market orientation, financial literacy and financial inclusion. This non-financial variables are expected to affect LPD performance in the long term. The non-financial variables in this study are intangible assets, which are expected to improve company performance towards competitive advantage, as revealed by the Resource Based Theory that the competitive advantage and company performance depend on tangible and intangible resources (Das \& Teng, 2000).

Efforts to create opportunities to overcome low performance require the application of management functions according to the concept of entrepreneurial orientation (Lee \& Peterson, 2000). Companies with entrepreneurial orientation are driven to always do innovativeness, risk-taking, proactiveness, and aggressiveness that have a significant impact on performance (Taheri et al., 2019).Entrepreneurial orientation is the level where companies are able to be more proactive, innovative, and dare to take risks which are seen as having implications in improving business performance (Keh et al., 2007). Risk taker is the attitude possessed by entrepreneurs and committed to developing resources and ready to face challenges, or being actively involved in business strategies that have an impact on situations of high uncertainty, proactively reflecting the commitment of an entrepreneur to be ready to compete through a combination of aggressive and proactive attitudes, such as innovating in new products or services above the competition and business activities to anticipate future demand. future and invent a change and create a new environment, innovative is defined as an entrepreneurial attitude that involves himself creatively in the process of experimenting with new ideas that have the potential to create new production methods so as to produce profits. new products or services for current and new markets. A high entrepreneurial orientation is related to the main driver in forming profits so that an entrepreneur has the opportunity to make profits from the emergence of these opportunities, so that it has a positive effect on business performance (Wiklund, 1999).

Other empirical evidence showing that there is a positive influence between entrepreneurial orientation and business performance has also been investigated by (Covin \& 
Slevin, 1991) and (Wiklund, 1999), the higher the entrepreneurial orientation, the higher the organizational performance tends to be (Alvarez-Torres et al. , 2019; Ningsih et al., 2015; Stanley et al., 2019; Wibisono et al., 2020). Thus, the first hypothesis is formulated as follows.

$\mathrm{H}_{1}$ : Entrepreneurial orientation has a positive effect on performance

The company's efforts to find out consumer desires and competitors' movements in order to create customer satisfaction are called market orientation step (Haryanto et al., 2017). Market orientation is developed to create customer value added, which has important implications in building and improving performance (Slater \& Narver, 2000). "Market orientation is a description of customer needs and competition from competitors so that companies must have new strategies to achieve customer satisfaction in different ways" (Haryanto et al., 2017) "Organizations that apply a culture of orientation focus entirely on customer needs, compared to finding new customers. The businesses are active in understanding customer needs" (Theodosiou et al., 2012), "Market orientation has three main components, namely customer orientation, competitor orientation, and inter-functional coordination (Idar et al., 2012) and (Taleghani et al., 2013). Market orientation "can significantly improve company performance (Nur \& Salim, 2014; Sutika \& Sujana, 2013; Solikahan \& Mohammad, 2019; Wibisono et al., 2020) Based on this, the following hypotheses can be formulated.

$\mathrm{H}_{2}$ : Market orientation has a positive effect on performance.

Financial literacy is still being researched in developed and developing countries so that it becomes a major concern in causing rapid changes in the financial industry (Wachira \& Kihiu, 2012). It manages, analyzes and conveys financial conditions that improve companies' welfare (Lusardi, 2008). Financial literacy is the knowledge and "understanding of financial concepts and risks, skills, motivations and beliefs" which aims to to make effective financial decisions, thereby increasing personal and group financial well-being, so that it affects the economic field as a whole. In the long term (OECD, 2015), financial knowledge, skills and beliefs possessed by individuals have implications for their financial behavior, thus influencing active involvement in financial activities and more positive financial behavior. Those who have positive long-term attitude will have a high tendency and show "better financial behavior compared to individuals who have a short-term financial attitude (Atkinson \& Messy, 2011).

Small and Medium Enterprises (SMEs) in Kenya (Mutiso \& Muigai, 2018) and (Buchdadi et al., 2020) (Buchdadi et al., 2020) have shown that high financial literacy among SME owners lead to higher performance (Kimunduu et al., 2016). Conversely, the low level of financial literacy will make the financial condition of small businesses worse (Dahmen \& Rodríguez, 2014). Financial literacy in Microfinance Institutions such as Village Credit Institutions is needed in reading, analyzing, managing and communicating financial conditions to improve their performance. Based on this, the following hypotheses can be formulated,

$\mathrm{H}_{3}$ : Financial literacy has a positive effect on performance. 
The Financial Services Authority or OJK Regulation Number 76/POJK.07/2016 states that financial inclusion is the availability of access or choice of access to various products, financial services and institutions. The type of financial services is a source of funding that can be chosen by adjusting the capabilities and needs of the community as an effort to improve welfare. 'Financial inclusion regulations in Indonesia' have a target group of people who have limitation in terms of funding so that local businesses and independent businesses can be sustainable (POJK Number 76/POJK.07/2016 Concerning Improving Financial Literacy and Inclusion in the Financial Services Sector for Consumers and/or the Community, 2016). 'The Financial Inclusion Program provides opportunities for accessing credit and savings safely, and can avoid dependence on economically disadvantaged communities from informal credit sources that have high risks such as moneylenders (Sarma, 2010). Financial inclusion was found to be able to improve performance (Bongomin et al., 2017), (Oranga \& Ondabu , 2018), and financial inclusion has found a positive effect on performance (Sanistas yes et al., 2019; History et al., 2020; Issaias et al., 2021), Based on this, the hypothesis is formulated as follows,

$\mathrm{H}_{4}$ : Financial inclusion has a positive effect on sustainable performance.

\section{RESEARCH METHODS}

The number of LPDs operating in Bali Province as of 2019 were 241 units representing the population of this study. The determination of the sample size was carried out using the Slovin formula (Umar, 2004) which was 93 units. Sampling was done using proportionate stratified random sampling based on the health level of the LPDs. The questionnaire was prepared using a semantic differential approach 1 to 5 containing statements about research variables,

The dependent variable of this study is performance as is measured by credit volume growth, profit growth, asset growth, and customer growth (Aragón-Sánchez \& Sánchez-Marín, 2005). The independent variables include: (1) entrepreneurial orientation including innovative, proactive, risk taking (Theodosiou et al., 2012); (2) Market orientation uses the dimensions of customer orientation, competitor orientation, and inter-functional coordination (Haryanto et al., 2017); (3) Financial literacy uses the dimensions of financial attitude, financial behavior, financial skills, financial knowledge developed from Bongomin et al. (2017); (4) Financial Inclusion with indicators developed from research by Bongomin et al. (2017) includes penetration, Availability, and Usage, the analysis method used is Partial Least Square (PLS).

\section{RESULTS AND DISCUSSION}

Seventy four percent of respondents were male and 27 percent female. Based on age, 42 percent were $41-50$ years old, 27 percent were over 50, 28 percent were $31-40$ years old and $3 \%$ were 20-30 years old. In terms of the educational background, 51\% Bachelors, 21 percent Diploma and 28 percent High School. 
The research instrument was tested on 30 respondents before being used, to test the validity and reliability of the instrument. All instruments showed that the correlation of each statement item score to the total score of each variable had a significant $r$ value (rxy) at level 0.05, which means that all variables are valid, all questionnaire items also have a Cronbach alpha value greater than 0.60 , which means that the questionnaire items are reliable as a data collection tool in research.

All indicators have a loading factor value greater than 0.7 , which means that the research model has met the convergent validity requirements. Table 1. illustrates that all construct variables meet discriminant validity, this can be seen from the Average Variance Extracted (AVE) value. Table 1 also illustrates that the composite reliability value is in the interval $0.894-0.939$, this shows that the model has met the composite reliability criteria.

Table 1. Average Variance Extracted (AVE), Composite Reliability and R-square

\begin{tabular}{l|c|c|c|c}
\hline \multicolumn{1}{c|}{ Variable } & $\boldsymbol{A V E}$ & Akar $\boldsymbol{A V E}$ & $\begin{array}{c}\text { Composite } \\
\text { Reliability }\end{array}$ & $\boldsymbol{R}$-square \\
\hline Entrepreneurial orientation & 0.773 & 0.8792 & 0.909 & \\
Market orientation & 0783 & 0.8849 & 0.915 & \\
Financial literacy & 0.706 & 0.8402 & 0.922 & \\
Financial inclusion & 0.837 & 0.9149 & 0.939 & 0.762 \\
Performance & 0.678 & 0.8234 & 0.894 &
\end{tabular}

Source: Results of Data Analysis, 2020

The Goodness of Fit test uses the value of predictive-relevance (Q2) of 76.2\%, so the model can be said to have a relevant predictive value. This result informs that the model has a relative effect of 76.2 percent in observing the dependent variable (performance). The results of hypothesis testing are shown in Figure 1. and Table 2. 


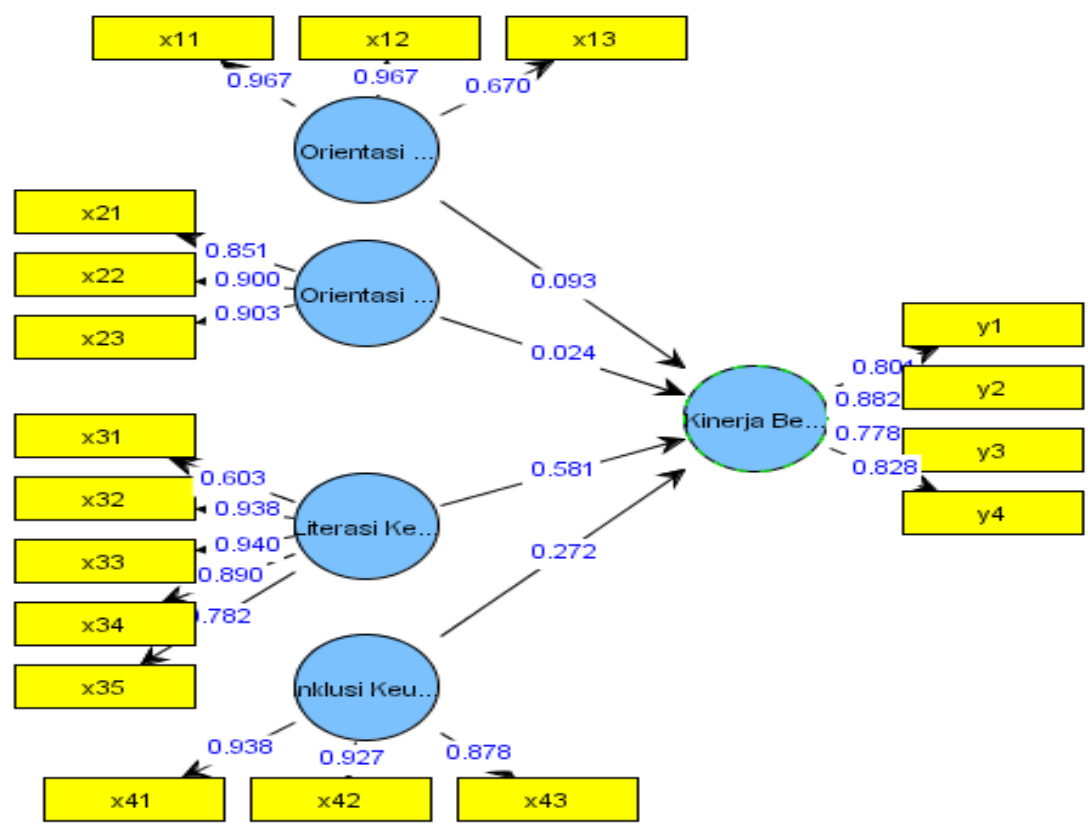

Figure 1. Output Partial Lest Square

Source: Results of Data Analysis, 2020

Table 2. Results of Hypothesis Testing

\begin{tabular}{l|c|c|c|c|c}
\hline \multicolumn{1}{c|}{ Variable } & $\begin{array}{c}\text { Original } \\
\text { Sample (O) }\end{array}$ & $\begin{array}{c}\text { Sample } \\
\text { Mean }(M)\end{array}$ & $\begin{array}{c}\text { Standard } \\
\text { Deviation } \\
(\text { STDEV })\end{array}$ & $\begin{array}{c}\text { t Statistics } \\
(\mid \text { OSTERR })\end{array}$ & Ket, \\
\hline $\begin{array}{l}\text { Entrepreneurial } \\
\text { orientation -> } \\
\text { performance }\end{array}$ & 0.024 & 0.057 & 0.092 & 2.225 & $\mathrm{Sig}$ \\
$\begin{array}{l}\text { Market orientation -> } \\
\text { performance }\end{array}$ & 0.093 & 0.094 & 0.046 & 2.028 & $\mathrm{Sig}$ \\
$\begin{array}{l}\text { Financial literacy -> } \\
\text { performance }\end{array}$ & 0.581 & 0.542 & 0.166 & 3.490 & $\mathrm{Sig}$ \\
$\begin{array}{l}\text { Financial inclusion -> } \\
\text { performance }\end{array}$ & 0.272 & 0.295 & 0.123 & 2.206 & $\mathrm{Sig}$ \\
\hline
\end{tabular}

Source: Results of Data Analysis, 2020

The path coefficient of the influence of entrepreneurial orientation on performance with a t-statistics value of 2.225 ( $>\mathrm{t}$ - critical is 1.96), indicating a significant positive influence of entrepreneurial orientation on performance. Thus, hypothesis $\mathrm{H} 1$ stating that entrepreneurial orientation has a positive effect on performance can be accepted. Entrepreneurial orientation was found to have a positive effect on performance. This means that LPDs in Bali can increase entrepreneurial orientation which is explained from the innovative, proactive and risk-taking dimensions in improving their performance, which includes loan volume growth, profit growth, asset growth and customer growth. The findings of this study reinforce the findings of previous studies (Alvarez-Torres et al., 2019; Ningsih et al., 2015; Stanley et al., 2019; Wibisono et al., 2020). 
The results of the PLS analysis show that the path coefficient of the influence of market orientation on financial performance with a t-statistics value of 2.028 (> t - critical is 1.96). This means that the effect of the orientation mock-up on performance is positive and significant. Thus, hypothesis $\mathrm{H} 2$ stating that market orientation has a positive effect on performance can be accepted. This finding shows that LPDs that only operate in the local Pekraman Village can improve customer orientation, competitor orientation and interfunctional coordination in improving their performance which is reflected in the growth of credit volume, profit growth, asset growth and customer growth. The findings of this study strengthen the research findings which found that market orientation can significantly improve company performance (Nur \& Salim, 2014; Solikahan \& Mohammad, 2019; Sutika \& Sujana, 2013; Wibisono et al., 2020).

The path coefficient of the effect of financial literacy on performance with a t-statistics value of 3,490 (>t - critical is 1.96), indicating a significant positive effect of financial literacy on performance. Thus, hypothesis $\mathrm{H} 3$ stating that the financial inclusion has a positive effect on performance is acceptable. This finding shows that the LPDs' Management in Bali as a rural microfinance institution, can increase knowledge, skills and financial confidence which is reflected in the dimensions of financial attitude, financial behavior, financial skills, and financial knowledge. They can improve their performance, which is reflected in the growth of credit volume, profit growth, asset growth and customer growth. The findings of this study strengthen the findings of previous studies that financial literacy has a positive effect on the performance of Small and Medium Enterprises (SMEs) in Kenya (Mutiso \& Muigai, 2018) and (Buchdadi et al., 2020). High financial literacy among SME owners leads to higher performance (Kimunduu et al., 2016). The low level of financial literacy will make the financial condition of small businesses worse (Dahmen \& Rodríguez, 2014).

The path coefficient of the effect of financial inclusion on performance with a tstatistics value of 2.206 ( $>\mathrm{t}$ - critical is 1.96), indicating the effect of financial inclusion on performance is positive and significant. Thus, hypothesis $\mathrm{H} 4$ stating that financial inclusion has a positive effect on performance is acceptable. This finding means that LPD can increase penetration, able to attract customers; provide financial services; and usage. It is shown that access to third party funds can improve performance which is reflected in the growth of credit volume, profit growth, asset growth and customer growth. The findings of this study reinforce previous findings which found that financial inclusion was found to be able to improve performance (Oranga \& Ondabu, 2018) 2018), financial inclusion had a positive effect on performance (Issaias et al., 2021; History et al., 2020; Sanistasya et al. , 2019).

\section{CONCLUSIONS}

This study informs that non-financial variables which include entrepreneurship orientation, market orientation, financial literacy and financial inclusion have a strong impact in improving LPD performance as a rural microfinance institution based on local wisdom in Bali. This study strengthens the Resource Based Theory revealing that competitive advantage 
and company performance depend on tangible and intangible resources, where non-financial variables in this study are intangible assets that can improve LPD performance in Bali.

This research focuses on LPDs as rural microfinance institutions based on local wisdom, future researchers need to take research samples at formal financial institutions to be able to generalize the findings. In addition, future research is deemed necessary to explore other variables such as local culture of Bali in supporting the creation of market orientation and entrepreneurial orientation and financial inclusion in LPD as a rural microfinance institution.

\section{REFERENCES}

Alvarez-Torres, F. J., Lopez-Torres, G. C., \& Schiuma, G. (2019). Linking entrepreneurial orientation to SMEs' performance: Implications for entrepreneurship universities. Management Decision, 57(2), 3364-3386. https://doi.org/10.1108/MD-11-2018-1234

Aragón-Sánchez, A., \& Sánchez-Marín, G. (2005). Strategic orientation, management characteristics, and performance: A study of Spanish SMEs. Journal of Small Business Management, 43(3), 287-308. https://doi.org/10.1111/j.1540-627X.2005.00138.x

Atkinson, A., \& Messy, F. A. (2011). Assessing financial literacy in 12 countries: An OECD/INFE international pilot exercise. Journal of Pension Economics and Finance, 10(4), 657-665. https://doi.org/10.1017/S1474747211000539

Bongomin, G. O. C., Mpeera Ntayi, J., Munene, J. C., \& Akol Malinga, C. (2017). The relationship between access to finance and growth of SMEs in developing economies: Financial literacy as a moderator. Review of International Business and Strategy, 27(4), 520-538. https://doi.org/10.1108/RIBS-04-2017-0037

Buchdadi, A. D., Sholeha, A., Ahmad, G. N., \& Mukson. (2020). the Influence of Financial Literacy on Smes Performance Through Access To Finance and Financial Risk Attitude As. Academy of Accounting and Financial Studies Journal, 24(5), 1-16.

Covin, J. G., \& Slevin, D. P. (1991). A Conceptual Model of Entrepreneurship as Firm Behavior. Entrepreneurship Theory and Practice. https://doi.org/10.1177/104225879101600102

Dahmen, P., \& Rodríguez, E. (2014). Financial Literacy and the Success of Small Businesses: An Observation from a Small Business Development Center. Numeracy, 7(1). https://doi.org/10.5038/1936-4660.7.1.3

Das, T. K., \& Teng, B. S. (2000). A resource-based theory of strategic alliances. Journal of Management. https://doi.org/10.1177/014920630002600105

Haryanto, A. T., Haryono, T., Sri, H., \& Sawitri, R. (2017). International Review of Management and Marketing Market Orientation, Learning Orientation and Small Medium Enterprises Performance:The Mediating Role of Innovation. International Review of Management and Marketing, 7(1), 484-491.

Idar, R., Yusoff, Y., \& Mahmood, R. (2012). The Effect of Market Orientation as Mediator to Strategic Planning Practices and Performance Relationship: Evidence from Malaysian 
SMEs. Procedia Economics and Finance, 4, 68-75. https://doi.org/10.1016/s22125671(12)00322-x

Issaias, L. A., Odondo, A. J., \& Okelo, S. (2021). Effect of Financial Inclusion on Performance of Microfinance Banks in Kenya. The International Journal of Business \& Management, 9(2), 287-298. https://doi.org/10.24940/theijbm/2021/v9/i2/bm2102-036

Keh, H. T., Nguyen, T. T. M., \& Ng, H. P. (2007). The effects of entrepreneurial orientation and marketing information on the performance of SMEs. Journal of Business Venturing. https://doi.org/10.1016/j.jbusvent.2006.05.003

Kimunduu, G., Erick, O., \& Shisia, A. (2016). A study on the influence of financial literacy on financial performance of small and medium enterprises in Ruiru Town, Kiambu County, Kenya. International Journal of Economics, Commerce and Management United Kingdom, IV(11), 416-433.

Krisnia Putri, I. G. A. N., \& Mustanda, I. K. (2019). Pengaruh Kecukupan Modal, Likuiditas, Dan Non Performing Loan Terhadap Profitabilitas Pada Lpd Di Kota Denpasar. E-Jurnal $\begin{array}{llll}\text { Manajemen Universitas } \quad \text { Udayana, } & 8(6), & 3360 .\end{array}$ https://doi.org/10.24843/ejmunud.2019.v08.i06.p03

Kumalasari, P. D., Putu, N., \& Ernawatiningsih, L. (2014). The Determinants of Profitability in Village Credit. 11, 41-45.

Lee, S. M., \& Peterson, S. J. (2000). Culture, entrepreneurial orientation, and global competitiveness. Journal of World Business. https://doi.org/10.1016/S10909516(00)00045-6

Lusardi, A. (2008). W13824.

Mutiso, A. N., \& Muigai, R. G. (2018). An Assessment of Financial Literacy and the Performance of UWEZO Funded SME' $\mathrm{s}$ in Kirinyaga County, Kenya. Journal of Economics and Sustainable Development, 9(6), 10-17.

Ningsih, A. P., Luh, N., Wiagustini, N. L. P., Artini, S., Gede, L., \& Rahyuda, H. (2015). Organizational Culture, Decision of Funding and Financial Performance: An Evidence from Small and Medium Enterprises. European Journal of Business and Management, 7(32), 148-158.

Nur, N., \& Salim, U. (2014). Entrepreneurship Orientation, Market Orientation, Business Strategy, Management Capabilities On Business Performance; Study At Small And Medium Enterprise Printing In Kendari \&quot; International Journal of Business and Management Invention ISSN (Online, 3(12), 2319-8028.

OECD. (2015). G20/OECD Principles of Corporate Governance. In G20/OECD Principles of Corporate Governance. OECD Publishing. https://doi.org/10.1787/9789264257443-tr

Oranga, O. J., \& Ondabu, I. T. (2018). Effect of Financial Inclusion on Financial Performance of Banks Listed At the Nairobi Securities Exchange in Kenya. International Journal of Scientific and Research Publications (IJSRP), 8(5), 624-649. https://doi.org/10.29322/ijsrp.8.5.2018.p7779 
POJK Nomor 76/POJK.07/2016 tentang Peningkatan Literasi dan Inklusi Keuangan di Sektor Jasa Keuangan Bagi Konsumen dan/atau masyarakat, Pub. L. No. POJK Nomor 76/POJK.07/2016 (2016).

Riwayati, H. E., Salim, U., Maskie, G., \& Indrawati, N. K. (2020). Financial Inclusion and Performance to Mediate the Effect of Banking and Tax Regulation on the Success of Small and Medium Enterprises in Indonesia. International Journal of Economics and Business Administration, VIII(Issue 3), 517-533. https://doi.org/10.35808/ijeba/541

Sanistasya, P. A., Raharjo, K., \& Iqbal, M. (2019). The Effect of Financial Literacy and Financial Inclusion on Small Enterprises Performance in East Kalimantan. Jurnal Economia, 15(1), 48-59. https://doi.org/10.21831/economia.v15i1.23192

Sarma, M. (2010). Discussion Papers in Economics Index of Financial Inclusion. Centre for International Trade and Development School of International Studies. Jawaharlal Nehru University, 1-28.

Slater, S. F., \& Narver, J. C. (2000). The Positive Effect of a Market Orientation on Business Profitability: A Balanced Replication. Journal of Business Research, 48(1), 69-73. https://doi.org/10.1016/S0148-2963(98)00077-0

Solikahan, E. Z., \& Mohammad, A. (2019). Entrepreneurial Orientation, Market Solikahan, E. Z., \& Mohammad, A. (2019). Entrepreneurial Orientation, Market Orientation and Financial Orientation in Supporting the Performance of Karawo SMEs in Gorontalo City. Journal of Applied Management (JAM), 17(. Journal of Applied Management (JAM), 17(4), 729-740.

Stanley, L. J., Hernández-Linares, R., López-Fernández, M. C., \& Kellermanns, F. W. (2019). A Typology of Family Firms: An Investigation of Entrepreneurial Orientation and Performance. Family Business Review, 32(2), 174-194. https://doi.org/10.1177/0894486519838120

Sutika, I. K., \& Sujana, I. K. (2013). Analisis Faktor Kinerja Yang Mempengaruhi Profitabilitas Pada Lembaga Perkreditan Desa. E-Jurnal Akuntansi, 5(1), 53-67.

Taheri, B., Bititci, U., Gannon, M. J., \& Cordina, R. (2019). Investigating the influence of performance measurement on learning, entrepreneurial orientation and performance in turbulent markets. International Journal of Contemporary Hospitality Management. https://doi.org/10.1108/IJCHM-11-2017-0744

Taleghani, M., Gilaninia, S., \& Talab, S. M. (2013). Relationship between Market Orientation Culture and Business Performance. Journal of Contemporary Research Business, 5(1), 949-954.

Theodosiou, M., Kehagias, J., \& Katsikea, E. (2012). Strategic orientations, marketing capabilities and firm performance: An empirical investigation in the context of frontline managers in service organizations. Industrial Marketing Management, 41(7), 1058-1070. https://doi.org/10.1016/j.indmarman.2012.01.001

Umar, H. (2004). Metode Riset Ilmu Administrasi. PT Gramedia Pustaka Utama. 
Wachira, M., \& Kihiu, E. (2012). Impact of financial literacy on access to financial services in Kenya. International Journal of Business and Social ....

Wibisono, T., Universari, N., \& Budiati, Y. (2020). Market Orientation, Entrepreneurship Orientation, and Company Performance: Study on Small and Medium Industries (Smes) Furniture in Demak District. Economics and Business Solutions Journal, 4(1), 20. https://doi.org/10.26623/ebsj.v4i1.2240

Wiklund, J. (1999). The Sustainability of the Entrepreneurial Orientation--Performance Relationship.(Statistical Data Included). Entrepreneurship: Theory and Practice. 